Jurnal Kesehatan Karya Husada, Vol 9 No 1 Tahun 2021

PISSN 2337649X/EISSN 2655-8874

Indra Amanah, Miftahul Jannah "Intervensi Pelatihan untuk Meningkatkan Keterampilan,

Self Efficacy dan Pengetahuan Pemanfaatan Limbah Styrofoam Menjadi Batako pada

Komunitas Pemulung Sampah" (hal 34-40)

Received

Revisied

Acceptep

09 Desember 2020

19 Februari 2021

16 Juni 2021

\title{
INTERVENSI PELATIHAN UNTUK MENINGKATKAN KETERAMPILAN, SELF EFFICACY DAN PENGETAHUAN PEMANFAATAN LIMBAH STYROFOAM MENJADI BATAKO PADA KOMUNITAS PEMULUNG SAMPAH
}

\author{
Indra Amanah ${ }^{1)}$, Miftahul Jannah ${ }^{2)}$ \\ ${ }^{1}$ Fakultas Kesehatan, Universitas Mega Buana Palopo \\ Email: indra.amanah.andinurhayati@gmail.com \\ ${ }^{2}$ Fakultas Kesehatan, Universitas Mega Buana Palopo \\ Email: miftahul_jannah979@yahoo.com
}

\begin{abstract}
ABSTRAK
Banyaknya sampah yang dihasilkan dan tidak dikelola dengan baik dapat menimbulkan pencemaran. Pencemaran terjadi apabila masyarakat yang terbiasa membakar sampah, dan membuang sampah sembarang tempat seperti sungai atau kebun kosong serta menimbun sampah yang sulit terurai. Penglolaan sampah rumah tangga yang dikelola dengan baik sebesar 36,8\% dan jumlah sampah yang tidak dikelola dengan baik sebesar $63,2 \%$ dari jumlah sampah yang tertimbang sebanyak 282,654 ton. Tujuan dari penelitaan ini adalah untuk menilai pengaruh intervensi pelatihan terhadap keterampilan, self efficacy dan pengetahuan pemanfaatan limbah styrofoam menjadi batako. Penelitian ini merupakan penelitian pra eksperimen dengan rancangan one group pre test post test design, dilakukan pretest, kemudian diberikan treatment berupa pelatihan dan praktik daur ulang styrofoam menjadi batako. Setelah itu dalam jangka waktu kurang lebih 1 bulan setelah treatment dilakukan posttest untuk mengukur kembali self efficacy, pengetahuan dan keterampilan pemanfaatan limbah styrofoam menjadi batako yang bernilai ekonomis. Respondenya adalah pemulung sampah yang berjumlah 83 orang. Hasil nilai uji wilcoxon pada penelitian ini menunjukkan ada pengaruh pelatihan terhadap keterampilan dengan nilai $\mathrm{p}=0,000$, self efficacy $\mathrm{p}=0,000$ dan pengetahuan $\mathrm{p}=0,000$.
\end{abstract}

Kata kunci: Pelatihan, Styrofoam, Keterampilan, Self Efficacy, Pengetahuan

\begin{abstract}
The amount of waste produced and not managed properly can cause pollution. Pollution occurs when people are accustomed to burning rubbish, and littering any place such as rivers or empty gardens and piling up rubbish that is difficult to decompose. Good management of household waste is $36.8 \%$ and the amount of waste that is not managed properly both $63.2 \%$ of the total weighted waste of 282,654 tonnes. The purpose of this study was to assess the effect of training interventions on skills, self-efficacy and knowledge of using Styrofoam waste into bataco. This research is a pre-experimental study with a one group pre test post test design, conducted a pretest, then given treatment in the form of training and practice recycling styrofoam into concrete blocks. After that, within a period of approximately 1 month after treatment, a posttest is carried out to re-measure the self-
\end{abstract}


Jurnal Kesehatan Karya Husada, Vol 9 No 1 Tahun 2021

PISSN 2337649X/EISSN 2655-8874

Indra Amanah, Miftahul Jannah "Intervensi Pelatihan untuk Meningkatkan Keterampilan,

Self Efficacy dan Pengetahuan Pemanfaatan Limbah Styrofoam Menjadi Batako pada

Komunitas Pemulung Sampah" (hal 34-40)

efficacy, knowledge and skills of using Styrofoam waste to become economically valuable concrete blocks. The respondents were trash scavengers, amounting to 83 people. The results of the Wilcoxon test value in this study indicate that there is an effect of training on skills with a value of $p=0,000$, self-efficacy $p=0,000$ and knowledge $p=0,000$.

Keywords: Training, Styrofoam, Skills, Self Efficacy, Knowledge

PENDAHULUAN

Jumlah volume sampah di

Sulawesi Selatan, setiap hari mencapai 1000 ton/hari, sampah yang tidak diolah mencapai 425 ton/hari. Angka ini akan terus meningkat setiap tahunnya mengingat bahwa penduduk Indonesia semakin tahun akan terus bertambah dan akan berpengaruh besar terhadap peningkatan volume sampah khususnya sampah anorganik (Kementerian Lingkungan Hidup dan Kehutanan RI, 2018; Dinas Lingkungan Hidup, 2018) Pengelolaan sampah rumah tangga di Sulawesi Selatan yang dikelola dengan baik sebesar $35,8 \%$ dan yang tidak dikelola dengan baik sebesar $64,2 \%$ dari jumlah sampah yang tertimbang sebanyak 8,677 ton (Kementerian Kesehatan Republik Indonesia, 2018). Perilaku 3R (Reuse, Reduce, Recycle) masih jarang dilakukan. Persentase yang paling sering memperlakukan sampah dengan dengan mendaur ulang 0,19\%, menjadikan pupuk kompos $0,53 \%$, dimanfaatkan untuk makanan hewan $0,26 \%$, masih kurang dari $1 \%$.
Sementara sekitar $54,65 \%$ rumah tangga paling sering membuang sampah dengan cara dibakar (Kesehatan, 2018). Penglolaan sampah rumah tangga yang dikelola dengan baik sebesar $36,8 \%$ dan jumlah sampah yang tidak dikelola dengan baik sebesar 63,2\% dari jumlah sampah yang tertimbang sebanyak 282,654 ton (Kementerian Lingkungan Hidup dan Kehutanan RI, 2018; Sucipto, C, 2012)

$$
\begin{aligned}
& \text { Banyaknya jumlah sampah } \\
& \text { yang dibuang setiap harinya } \\
& \text { menunjukkan bahwa dalam setiap } \\
& \text { harinya masyarakat memproduksi } \\
& \text { sampah dengan jumlah yang banyak. } \\
& \text { Banyaknya sampah yang dihasilkan } \\
& \text { dan tidak dikelola dengan baik dapat } \\
& \text { menimbulkan pencemaran. }
\end{aligned}
$$
Pencemaran terjadi apabila masyarakat yang terbiasa membakar sampah, dan membuang sampah sembarang tempat seperti sungai atau kebun kosong serta menimbun sampah yang sulit terurai seperti Styrofoam (Abida, 2017; Sumantri, 2015). Untuk mengatasi masalah tersebut, maka perlu 
Jurnal Kesehatan Karya Husada, Vol 9 No 1 Tahun 2021

PISSN 2337649X/EISSN 2655-8874

Indra Amanah, Miftahul Jannah "Intervensi Pelatihan untuk Meningkatkan Keterampilan,

Self Efficacy dan Pengetahuan Pemanfaatan Limbah Styrofoam Menjadi Batako pada

Komunitas Pemulung Sampah" (hal 34-40)

dilakukan suatu upaya untuk

\section{METODE}

meningkatkan pengetahuan, self

Penelitian ini merupakan penelitian

efficacay serta keterampilan

masyarakat dalam mendaur ulang atau

memanfaatkan kembali sampah

menjadi bahan yang berguna sebagai

wujud kepedulian terhadap lingkungan

dan kesehatan. Seperti halnya

penelitian yang dilaksanakan

menunjukkan bahwa faktor edukasi

dalam hal ini pelatihan, merupakan

faktor yang paling memegang peranan

penting dalam keberlangsungan

kerajinan berbasis sampah di dusun

sukunan (Atmaji, 2017; Wirahadi,

2016). Sebgaimana dalam penelitian

ini berdasarkan hasil wawancara dengan responden yang merupakan pemulung menyatakan bahwa mereka sama sekali belum pernah diberikan pelatihan terkait dengan pemanfaatan sampah styrofoam, sehingga belum mengetahui caranya, apalagi untuk mempraktikkan pengolahan atau pemanfaatanya sama sekali belum memiliki gambaran. Hal ini juga mendasari penelitian untuk memberikan perlakukan berupa pelatihan pemanfaatan limbah styrofoam pada pemulung sampah di Kota Palopo. pra eksperimen dengan rancangan one group pre test post test design (Creswell, 2016) Dilakukan pretest, kemudian diberikan treatment berupa pelatihan dan praktik daur ulang styrofoam menjadi batako. Dalam prosesnya pelatihan terbagi beberapa sesi yakni: sesi 1 pemaparan materi dan pemutaran video serta penjelasan tekhnis pengolahan sampah styrofoam, sesi 2 simulasi dan praktik, responden mempraktikkan cara pengolahan sampah styrofoam menjadi bahan bangunan berupa batako pada saat pelatihan. Setelah itu dalam jangka waktu kurang lebih 1 bulan setelah treatment dilakukan posttest untuk mengukur kembali self efficacy, pengetahuan dan keterampilan pemanfaatan limbah styrofoam menjadi batako. Jumlah responden dalam penelitian ini adalah 83 orang pemulung yang dipilih secara purposive . Data yang diperoleh dalam penelitian ini dianalisis menggunakan uji wilcoxon.

\section{HASIL DAN PEMBAHASAN}

Tabel 1. Distribusi responden berdasarkan jenis kelamin 
Jurnal Kesehatan Karya Husada, No 9 Vol 1 Tahun 2021

PISSN 2337649X/EISSN 2655-8874

Indra Amanah, Miftahul Jannah "Intervensi Pelatihan untuk Meningkatkan Keterampilan,

Self Efficacy dan Pengetahuan Pemanfaatan Limbah Styrofoam Menjadi Batako pada

Komunitas Pemulung Sampah" ( ha 1 34-

\begin{tabular}{|c|c|c|}
\hline $\begin{array}{l}\text { Jenis } \\
\text { kelamin }\end{array}$ & Frekuensi (f) & $\begin{array}{c}\text { Persentase } \\
(\%)\end{array}$ \\
\hline Laki-laki & 28 & 33,73 \\
\hline Perempuan & 55 & 66,27 \\
\hline Total & 83 & 100 \\
\hline
\end{tabular}

Sumber: Data primer, 2020

Pada tabel 1 menunjukkan dari

83 responden, distribusi jenis kelamin laki-laki sejumlah $28(33,73 \%)$ orang pemulung dan yang berjenis kelamin perempuan sebanyak $55(66,27 \%)$ orang pemulung.

Tabel 2. Pengaruh pelatihan terhadap keterampilan pemanfaatan limbah styrofoam.

\begin{tabular}{|c|c|c|c|}
\hline & Mean & $S D$ & $p$-value \\
\hline Pretest & 20,59 & 5,25 & \multirow{2}{*}{0,000} \\
\hline Posttest & 34,98 & 0,15 & \\
\hline
\end{tabular}

Ket: Uji wilcoxon

Berdasarkan pada tabel 2, dari hasil analisis uji Wilcoxon diperoleh nilai mean para pretest keterampilan= 20,59 dan posttest $=34,98$ dan nilai $\mathrm{p}$ pretest dan posttest adalah 0,000 atau kurang dari 0,05. Pada penelitian ini juga diperoleh bahwa sebelum diberikan pelatihan para pemulung sama sekali belum dapat mempraktikkan cara pengolahan sampah Styrofoam, namun setelah diberikan pelatihan mereka secara trampil dapat mempraktikkan hingga menghasilkan karya yang bernilai ekonomis berupa batako dari limbah
Styrofoam. Hal ini menunjukkan bahwa perbedaan nilai rata-rata/mean antara pretest dengan posttest. Hasil penelitian ini juga sejalan dengan penelelitian yang telah dilakukan oleh Kurniaty \& Rizal (2011) tentang pemanfaatan hasil pengelolaan sampah sebagai alternatif bahan bangunan konstruksi. Selain itu juga ada penelitian yang memiliki pengaruh yakni penelitian yang dilakukan oleh Marliani (2015) tentang pemanfaatan limbah rumah tangga (sampah anrorganik) sebagai bentuk implementasi pendidikan lingkungan.

Tabel 3. Pengaruh pelatihan terhadap self efficacy pemanfaatan limbah styrofoam.

\begin{tabular}{llll}
\hline & Mean & $S D$ & p-value \\
\hline Pretest & 13,17 & 2,28 & 0,000 \\
Posttest & 27,98 & $\underline{0,15}$ &
\end{tabular}

Ket: Uji wilcoxon

Data pada tabel 3 menunjukkan bahwa diperoleh nilai mean pretest self efficacy adalah 13,17 dan posttest 27,98. Hasil analisis menggunakan uji Wilcoxon diperoleh nilai $\mathrm{p}$ self efficacy adalah 0,000 hal ini berarti bahwa ada perbedaan sebelum dan setelah dilakukan pelatihan. Sebagiamamana pada 
Jurnal Kesehatan Karya Husada, No 9 Vol 1 Tahun 2021

PISSN 2337649X/EISSN 2655-8874

Indra Amanah, Miftahul Jannah "Intervensi Pelatihan untuk Meningkatkan Keterampilan,

Self Efficacy dan Pengetahuan Pemanfaatan Limbah Styrofoam Menjadi Batako pada Komunitas Pemulung Sampah" (hal 34-40)

penelitian yang dilakukan oleh tentang pemberdayaan berbasis

Purwaningrum (2016), terkait upaya mengurangi timbulan sampah plastik di lingkungan. Penelitian yang lain juga menunjukkan seperti yang dilakukan oleh Dewi (2017) tentang pemberdayaan melalui program daur ulang sampah plastik di kelompok pengelola sampah yang memiliki pengaruh.

Tabel 4. Pengaruh pelatihan terhadap pengetahuan pemanfaatan limbah styrofoam.

\begin{tabular}{llll}
\hline & Mean & $S D$ & p-value \\
\hline Pretest & 3,64 & 1,35 & 0,000 \\
Posttest & 11,89 & 0,31 & \\
\hline
\end{tabular}

Ket: Uji wilcoxon

Dari hasil penelitian pada tabel

4 diperoleh bahwa nilai mean pretest adalah 3,64 dan posttest adalah11,89 dan diperoleh hasil analisis mengguanakn uji wilcoxon diperoleh nilai $\mathrm{p}$ pengetahuan adalah 0,000 . Hal ini menunjukkan bahwa ada pengaruh pelatihan yang signifikan dengan adanya perbedaan nilai pretest dan posttest. Adapun penelitian lain juga yang dilakukan oleh Santoso \& Widodo (2011) terkait pemanfaatan limbah styrofoam dan juga penelitian yang dilakukan oleh Atmaji (2017) sampah yang mampu ningkatkan pengetahuan responden.

Penelitian ini juga didukung oleh social cognitive theory yang dikemukakan oleh Bandura, (2005) bahwa perilaku manusia sebagai interaksi timbal balik antara faktor personal, faktor perilaku dan faktor lingkungan yang saling mempengaruhi satu sama lain pada, pengetahuan merupakan bagian dari faktor personal sedangkan self efficacy dan keterapilan merupakan bagian dari faktor perilaku - Selain itu juga terdapat penelitian lain terkait pengelolaan sampah rumah tangga berbasis masyarakat yang dapat meningkatkan pengetahuan masyarakat dlam pengelolaaan sampah (Faizah, 2008).

\section{SIMPULAN DAN SARAN}

\section{Kesimpulan}

Ada pengaruh pelatihan terhadap keterampilan, self efficacy, dan pengetahuan pemanfaatan limbah styrofoam menjadi batako pada komunitas pemulung sampah di Kota Palopo.

\section{Saran}

1. Dinas lingkungan hidup dapat mengadaptasikan pelatihan ini 
Jurnal Kesehatan Karya Husada, No 9 Vol 1 Tahun 2021

PISSN 2337649X/EISSN 2655-8874

Indra Amanah, Miftahul Jannah "Intervensi Pelatihan untuk Meningkatkan Keterampilan,

Self Efficacy dan Pengetahuan Pemanfaatan Limbah Styrofoam Menjadi Batako pada

Komunitas Pemulung Sampah" (hal 34-40)

untuk diterapkan kepada

kelompok pemulung yang lain.

2. Pemerintah melalui dinas lingkungan hidup yang menaungi bidang kebersihan perlu banyak mensosialisasikan terkait pemanfaatan limbah Styrofoam dan menjalin kerjasama dengan pihak swasta konsumer hasil karya para pemulung sebagai langkah minimalisir sampah yang tidak terolah.

\section{DAFTAR PUSTAKA}

Abida, H. N. (2017). Model Pemberdayaan Lingkungan dan Pemberdayaan Ekonomi Masyarakat melalui Daur Ulang Sampah di Kampung Wisata

Lingkungan Sukunan. Social Studies, 6(6), 654-667.

Atmaji, L. T. (2017). Pengelolaan Usaha Kerajinan Berbasis Pemberdayaan Sampah di Dusun Sukunan, Desa Banyuraden, Kabupaten Sleman. Jurnal Tata Kelola Seni, 2(2), 1-6. https://doi.org/10.24821/jtks.v2i2 .1818

Bandura, A. (2005) The Evolution of Social Cognitive Theory, Great Minds in Management. Edited by 
Jurnal Kesehatan Karya Husada, No 9 Vol 1 Tahun 2021

PISSN 2337649X/EISSN 2655-8874

Indra Amanah, Miftahul Jannah "Intervensi Pelatihan untuk Meningkatkan Keterampilan, Self Efficacy dan Pengetahuan Pemanfaatan Limbah Styrofoam Menjadi Batako pada Komunitas Pemulung Sampah" (hal 34-40)

Kesehatan, K. K. B. P. dan P. (2018).

Sampah. Yogyakarta: Nuha

Hasil Utama Riset Kesehatan Medika.

Dasar. Kementrian Kesehatan

Sumantri. (2015). Kesehatan

Republik Indonesia, 1-100. Lingkungan. Jakarta: Kencana.

https://doi.org/1 Desember 2013

Kurniaty, D. R., \& Rizal, M. (2011).

Wirahadi, M. (2016). Elemen Interior

Pemanfaatan Hasil Pengelolaan

Berbahan Baku Pengolahan Sampah Styrofoam Dan Sampah

Sampah sebagai Alternatif Bahan Kulit Jeruk. None, 5(2), 144-153.

Bangunan Konstruksi. Jurnal

Smartek, 9(1), 47-60.

Marliani, N. (2015). Pemanfaatan

Limbah Rumah Tangga (Sampah

Anorganik) Sebagai Bentuk

Implementasi dari Pendidikan

Lingkungan Hidup. Formatif:

Jurnal Ilmiah Pendidikan MIPA, $4(2)$, $124-132$.

https://doi.org/10.30998/formatif.

$\mathrm{v} 4 \mathrm{i} 2.146$

Purwaningrum, P. (2016). Upaya

Mengurangi Timbulan Sampah

Plastik di Lingkungan. 8(2), 141-

147.

Santoso, A., \& Widodo, S. (2011).

Pemanfaatan Limbah Styrofoam (

Expanded Polysterene ) Untuk

Pembuatan Dinding. VII(1), 1-

18.

https://doi.org/10.1109/ICCV.201

3.269

Sucipto, C, D. (2012). Teknologi

Pengolahan dan Daur Ulang 